\title{
Yhtiömuotoiseen koneyhteistyöhön siirtyminen
}

Lari Poutiainen², Seppo Mönkkönen ${ }^{1}$, Pasi Eskelinen ${ }^{1}$, Anne-Mari Heikkinen ${ }^{1}$, Pirjo Suhonen ${ }^{1}$

1)Savonia-ammattikorkeakoulu, PL 72, 74101 Iisalmi, etunimi.sukunimi@savonia.fi

2) Savonia-ammattikorkeakoulu, lari.poutiainen@gmail.com

\section{TIIVISTELMÄ}

Yhteistyön tekemisellä maataloudessa on pitkät perinteet. Sen avulla on mahdollistettu riittävä työvoima kaikille tiloille sesongin aikana, parannettu koneiden käyttöastetta, mahdollistettu tehokkaampia koneketjuja ja luotu sosiaalisia verkostoja. Yhteistyössä on voimaa myös tulevaisuudessa. Uudet yritysmuodot ovat tulleet uusimpana yhteistyömuotona maataloussektorille esimerkiksi osakeyhtiömuotoisten yhteisnavetoiden muodossa.

Tässä työssä tutkittiin yhtiömuotoisen yhteisyrittämisen mahdollisuuksia koneyhteistyössä. Tarkasteltava yhtiömuoto on osakeyhtiö. Tarkoituksena oli selvittää, onko maatilayritysten omistamalla osakeyhtiöllä, joka tuottaa ja myy palveluita takaisin omistajilleen, toimintamahdollisuus ja mitkä ovat toiminnan lainalaisuudet. Työssä perehdytään kirjallisuuskatsauksen avulla osakeyhtiöön yhtiömuotona ja pohditaan myös yhteistyön yleisiä lähtökohtia.

Tutkimuksellisessa osassa on toteutettu case-tutkimus. Tutkimuksen aineisto on koottu haastattelemalla kohteeksi soveltuvien yritysten edustajia. Kohdeyritykset ovat maanviljelijöiden omistamia yhtiöitä, jotka myyvät pääosin suurimman osan tuottamistaan palveluista omistajilleen. Tämän lisäksi työssä on haastateltu maatilarahoituksen asiantuntijaa yhtiön rahoitusmahdollisuuksien selvittämiseksi.

Haastatteluaineistoon ja kirjallisuuskatsaukseen pohjautuen työssä pohditaan yhteistyöyrityksen toimintaympäristöä. Case-tutkimuksen lopputulemana esitellään kaksi esimerkkiyhtiötä, jotka tuottavat koneurakointipalveluja omistajilleen. Case-yhtiöiden avulla havainnollistetaan, kuinka yhteistyöyhtiö perustetaan ja miten sen kautta tuotettujen palveluiden kustannustehokkuutta voidaan arvioida.

Olemassa olevan tiedon, haastattelujen ja case sovellusten perusteella voidaan todeta, että yhtiömuotoinen yhteistyö on sekä juridisesti että taloudellisesti mahdollista. Toteutuessaan toiminnan tulee kuitenkin muistuttaa ammattimaista urakointitoimintaa. Toiminta vaatii tiettyä tarkkuutta, esimerkiksi palvelujen hinnoittelussa ja muussa osakkaiden ja yrityksen välisessä rahaliikenteessä, mutta esteitä ei muodostu. Yhtiö ei vaikuta suoraan toiminnan taloudellisuuteen, vaan on vain instrumentti tehdä työtä.

Työn aihealue on laaja ja tutkimus pyrkii esiselvitysmäisesti käymään läpi yhtiömuotoisessa yhteistyössä huomioitavia tekijöitä. Työ avaa monia mahdollisuuksia jatkotutkimuksille, joissa voidaan esimerkiksi casemuotoisesti keskittyä yhteen tapaukseen ja näin paljon tarkemmin vertailla esimerkiksi yhtiön perustamisen vaikutusta omistavien tilojen toimintaan.

Asiasanat: yhteistyö, yhteisomistus, osakeyhtiöt, konekustannukset 


\section{Johdanto}

Yhtiömuotoinen koneyhteistyö maatilojen välillä tarkoittaa tukitoimintojen yhtiöittämistä niin, että toiminnon tuottaa esimerkiksi osakeyhtiö ja omistavat viljelijät tai muut maatalouden toimijat ostavat yhtiön tuottamat palvelut ja korvaavat näin itse tehtyjä työvaiheita. Se mitä yhtiömuotoinen yhteistyö todellisuudessa on, riippuu todella paljon siitä, miten se on järjestetty. Yhteistyö voi muistuttaa koneasematoimintaa, jonka omistajapohja muodostetaan palvelun ostajien keskuudesta. Se voi myös muistuttaa yhteisomistusta, jolloin yhtiö esimerkiksi omistaa peltotyökoneita tai kuivaamon ja vuokraa niitä tietyllä hintaperusteella osakkailleen ja mahdollisesti ulkopuolisillekin.

Tässä tutkimuksessa on 2014-2015 etsitty Suomesta esimerkkiyhtiöitä, jossa viljelijät omistavat yhtiön, jolta itse ostavat palveluita. Tutkimuksessa perehdytään olemassa oleviin yhtiöihin, niiden perustamiseen toimintaan ja kokemuksiin toteutuksesta. Case-tutkimuksen soveltavassa osiossa avataan esimerkkiyhtiöiden avulla osakeyhtiön perustamista, yhtiön toiminnan suunnittelua sekä arvioidaan toiminnan taloudellisuutta. Tärkein ongelma oli selvittää, miten yhtiössä toimiminen vaikuttaa yhteistyöhön ja mitä etuja ja haittoja se tuo mukanaan.

Yhteistyötä ja yhteisyrittämistä käsitellään niin, että se on sovellettavissa kaikille maatalousyrittämisen osa-alueille, kuitenkin pääosin maidontuotannon näkökulmasta. Työn on tehty yhteistyössä MAITO-hankkeen kanssa.

\section{Aineisto ja menetelmät}

Kyseessä on case-tutkimus, jossa kartoitetaan olemassa olevien yritysten pohjalta yhteistyöyritysten toimintaympäristöä. Case-yritys on tässä tapauksessa anonyymi toimija, jonka tarkoitus on tuottaa omistajilleen konepalveluja.

Olemassa olevien yhtiömuotoisten koneyhteistyön selvitetään teemahaastatteluin. Haastateltavat yritykset (6) on valikoitu tutkimukseen arvioimalla niiden sopivuutta aihealueeseen. Koska osakeyhtiömuotoista yhteistyötä on melko vähän ja sitä ei ole tilastoitu erikseen, yhtiöt etsittiin haastateltaviksi yhteistyökumppaneiden kautta. Tutkimuksen yhteydessä kerätty haastatteluaineisto litteroitiin. Kaikkiaan työssä toteutetaan kuusi haastattelua, joista yksi on asiantuntijahaastattelu ja muut yrityshaastatteluja.

Case-menetelmällä luodaan kaksi erilaista yhteistyöyhtiötä. Yhtiöt ja niiden toiminta pohjautuvat haastateltaviin yrityksiin, mutta mikään ei kuvaa suoraan yhtä haastatelluista yrityksistä. Toimintamallit ovat kuitenkin oikeasti käytössä olevia, jotta case-yritysten uskottavuus säilyy.

Malliyritysten pohjalta työssä tehdään esimerkkisopimuksia. Sopimusten tarkoituksena on havainnollistaa yhtiön perustamisvaiheen sopimusten laatimista sekä painottaa tekijän näkemyksiä siitä, mitkä asiat ovat sopimisen arvoisia, vaikka osakeyhtiölaki ei niistä päättämään määräisikään. Taloudellinen tarkastelu sisältää vain yhtiön kustannusten arviointia ja niitä verrataan urakointina ostettavan palvelun hintaan.

Kustannusten arvioinnissa on käytetty apuna Työtehoseuran TTS-Kone ohjelmaa. TTS-Kone on Työtehoseuran julkaisema ohjelma, jonka tietokanta päivittyy vuosittain. Ohjelmassa on tiedot keskimääräisistä työvaiheiden urakointihinnoista ja esimerkiksi työkoneiden hankinta- ja jälleenmyyntihintaarviot. Syöttämällä ohjelmaan työkoneiden vuosittaiset käyttömäärät ja muuttuvat kustannukset saadaan ohjelmasta arvio koneketjun tuntikustannuksesta, jolla katetaan sekä kiinteät, että muuttuvat kustannukset. (TTS 2015.) Kun näitä hintoja verrataan keskimääräisiin urakointihintoihin, voidaan arvioida toiminnan mielekkyyttä. TTS-Kone huomioi laskuissa kiinteät kustannukset, poisto-, kunnossapito- ja korkokulut. Lisäksi se huomioi konetta kuljettavan henkilön palkan ja palkan sivukulut. Myös muuttuvat kustannukset kuten poltto- ja voiteluainekulut huomioidaan. Kuitenkin yrityksen johtamiseen kuluva työ ja mahdollinen osakkaille jaettava voitto puuttuu urakointihinnasta. Tämä määritetään laskelmissa liikevaihdosta laskettavalla keskimääräisellä kateprosentilla. Kate kattaa yrityksen kulut, jotka eivät liity varsinaisiin työvaiheisiin. 


\section{Tulokset ja tulosten tarkastelu}

\section{Kokemuksia yhteistyöyrityksestä}

Työssä haastateltiin lopulta viittä eri yritystä, jotka tekivät yhteistyötä yhtiömuotoisesti. Yhtiöistä kaksi oli kuivuriyhtiöitä, yksi oli lietteenlevitysyhtiö ja kahdessa yhteistyöyritys teki laajemmin eri kesäsesongin työvaiheita. Haastatellut yritykset sijaitsevat Pohjois-Savossa ja Pohjois-Pohjanmaalla. Yhtiöiden yhtiömuoto oli yhtä lukuun ottamatta osakeyhtiö. Toinen laaja-alaisista yhteistyöyhtiöistä oli osuuskunta. Yhtiömuodon vaikutukset yhtiöiden käytännön toimintaan olivat lopulta todella pieniä, mikäli yhtiön tuloksenjakoa ei lasketa. Koska suurimmassa osassa yhtiöitä tulosta ei jaettu, vaan pääpainopiste oli lähinnä palvelun tuottamisessa omistajille, ei yhtiömuoto noussut tutkimuksessa merkittävästi vaikuttavaksi tekijäksi.

Yhtä lukuun ottamatta kaikki haastatellut yritykset ( $80 \%$ haastatelluista yrityksistä) olivat syntyneet tarpeesta tuottaa maatilalle joitakin palveluita. Yhden taustalla oli sekä oman tilan palveluiden tuottaminen, mutta myös yrittäjien toimeentulon tuova koneasematoiminta. Tämä olikin ainoa tila, jolla selvä pääpainopiste oli tukitoimintoja tuottavassa yrityksessä ja sen toiminnassa.

Kaikki tutkimukseen osallistuneet yritykset olivat perustamisvaiheessa olleet jollain tavalla tekemisissä asiantuntijoiden kanssa. Osa yrityksistä oli muodostunut hankkeista, osa oli hakenut apua neuvojilta ja osassa yrityksistä oli yritysneuvontaa tehneitä henkilöitä mukana. Asiantuntijapalveluita oli myös käytetty myöhemmin kaikissa yrityksissä ulkoistamalla kirjanpito.

Useampi haastateltava painotti toimijoiden yhteistyökykyisyyttä. Osa toi esille yhteistyöhön kasvamisen ja oppimisen. Yhtiön omistajakunnan valikoitumista painotettiin etenkin yhtiöissä, joissa yhteistä työskentelyä oli enemmän, eli muissa kuin kuivuriyhtiöissä. Yhdessä haastattelussa tuli esille, että yhteistyötä voi myös opiskella. Haastateltavan mielestä, jotta yhteistyöhön kyetään, täytyy jäsenillä olla jonkin tasoista ennakoivaa talousajattelua ja strategisen johtamisen taitoja. Yhteistyötä tekevien tilojen täytyy kyetä suunnittelemaan ja ennakoimaan oman tilan toimintaa, jotta se voidaan sovittaa yhteen yhteistyön kanssa.

Yksi haastatelluista henkilöistä painotti osakeyhtiön perustamisen yhteydessä osakkeiden riittävän määrän tärkeyttä. Osakkeita kannattaisi yhtiössä olla kymmeniä tuhansia. Suuri osakemäärä ei vaikuta mitenkään yhtiön toimintaan, mutta helpottaa mahdollisia myöhempiä toiminnan muutoksia. Jos yhtiön omistusta halutaan siirtää tai osuuksia myydä, tuo suuri osakemäärä tähän joustavuutta. Osakkeiden myöhempi puolittaminen on paljon hankalampaa.

Päätöksen teko yhtiöissä oli ollut kaikissa sopuisaa, ja kokoukset olivat toimineet enemmänkin leimasimen roolissa. Osassa yhtiöitä koettiin, että osakeyhtiön vaatima byrokratia oli jopa turhaa, koska päätöksenteko sujuisi ilman sitäkin. Yksikään yhtiöistä ei ollut kohdannut vakavaa ristiriitatilannetta osakkaiden välillä toimintansa aikana.

Työn hinnoitteluperusteet vaihtelivat toimintamallin ja yritysten välillä. Kuivaamoyhtiöiden hinnoittelu perustui kuivurin käyttötunteihin ja toisella yhtiöistä myös eränvaihtoon kuluva aika oli hinnoiteltu. Lietteenlevitysyhtiö hinnoitteli työnsä kuutioperusteisesti. Laajemmin sesonkityövaiheita tehneistä yhtiöistä toinen hinnoitteli työnsä hehtaariperusteisesti ja toinen tuntiperusteisesti. Laskukaavat hinnan takana vaihtelivat paljon. Osa yhtiöistä sääti hinnoittelua vuosittain verraten sitä edellisen vuoden tulokseen ja arvioiden kustannusmuutosta tulevalle kaudelle. Osan hinta perustui puhtaasti markkinoiden muiden toimijoiden hinnasta johdettuun järkevään palvelun ostohintaan. Suurin osa hinnoista johdettiin kuitenkin kustannusarvion pohjalta. Yhdessä yhtiössä tämän kustannusarvion päälle laskettiin kiinteä kate, joka muodosti yrityksen tuloksen. Muut pyrkivät saamaan yrityksensä kohtalaisen lähelle nolla-tulosta.

Yhdessäkään haastatellussa yhtiössä osakkaat eivät olleet yhtiöön palkkasuhteessa. Yleisin omasta työstä korvauksen nostamisen menetelmä oli laskuttaa yhteistyöyhtiötä maatilayrityksen kautta, eli urakoida yhteistyöyritykselle. Kaksi laajemmin sesonkikauden eri työvaiheita tehnyttä yhtiötä käytti ansion maksussa myös pääomatuloa muodostavia reittejä. Osuuskunta maksoi osuuspääomankorkoa ja osakeyhtiöosinkoa.

Kaikki haastateltavat kokivat, että yhtiö on kustannustehokas tapa tuottaa palveluita. Joissakin haastatteluissa kuitenkin todettiin, että kannattava toiminta koneurakoinnin saralla on haastavaa. Yhtiöiden kannattavuuden kulmakivenä oli riittävä koneiden käyttöaste. Etenkin laajemmin satokauden palveluita tuottavissa yrityksissä oli tärkeää, ettei kalustoon hankinta työkoneita, joiden käyttöaste on todellisuudessa hyvin pieni. 


\section{Case-mallien rakentaminen}

Tutkimuksen case-yhtiöt ovat kuivuriyhtiö ja peltotyösuoritteita tuottava yhtiö. Kuivuriyhtiö syntyy alueelle, jolla on vajausta kuivauskapasiteetista, ja monen alueen viljelijän omistama kalusto on käyttöikänsä loppupäässä. Yritys, jolla tuotetaan peltopalveluita, puolestaan pyrkii poistamaan osakastiloilta kalustonhankintatarvetta ja tuottamaan peltotyöt kustannustehokkaammin.

Taulukossa 1 esitellään yritysten arvioituja vuotuisia työsuoritteita ja kustannusten perusteita, Taulukossa on esitetty työvaiheet, joita perustettava peltotyösuoritteita tarjoava yhtiö tekee. Siinä ovat rinnakkain perustettavan yhtiön työvaiheiden yksikkökustannusten arviot ja Työtehoseuran kyselyn kautta saadut keskimääräiset yksikköhinnat Suomessa.

TAULUKKO 1. Koneyhtiön katteettomat urakointihinnat verrattuna Työtehoseuran tilastoituihin hintoihin (soveltaen Palva 2013).

\begin{tabular}{|c|c|c|c|c|c|c|}
\hline \multirow[t]{2}{*}{ Työvaihe } & \multicolumn{2}{|c|}{$\begin{array}{c}\text { Työtehoseuran kyselyn } \\
\text { keskimääräinen urakointhinta } 2012\end{array}$} & \multicolumn{2}{|c|}{$\begin{array}{c}\text { Työtehoseuran kyselyn } \\
\text { urakointihintojen keskihajonta } 2012\end{array}$} & \multicolumn{2}{|c|}{$\begin{array}{l}\text { Case yhtiön työnkäytöllä saavutettu } \\
\text { vertailuikykyinen palvelun hinta }\end{array}$} \\
\hline & $\epsilon / h$ & €/ha & $\epsilon / h$ & $€ /$ ha & $€ / \mathrm{h}$ & €/ha \\
\hline Pintalevitys & 56,0 & 15,0 & $43-69$ & $12,3-17,8$ & 74,1 & 19,7 \\
\hline Kylvö & $65,5(2010)$ & 59,8 & & $44-76$ & 89,1 & 50,6 \\
\hline Rehunsiirtotyö & 60,0 & & $49-71$ & & 63,0 & \\
\hline Kyntö paluuauroilla & 62,1 & 55,6 & $42-79$ & $45-66$ & 62,4 & 74,9 \\
\hline Kyntö sarka-auroilla & 62,1 & 60,8 & $43-79$ & $45-86$ & 59,4 & 75,2 \\
\hline Viljan ajo & & & & & 60,0 & \\
\hline Traktorityö 71 - $140 \mathrm{~kW}$ & 48,1 & & $40-56$ & & 49,6 & \\
\hline Traktorityö 140 - $200 \mathrm{~kW}$ & 58,3 & & $51-66$ & & 50,0 & \\
\hline Traktorivuokraus & 22,0 & & $11-33$ & & 26,5 & \\
\hline
\end{tabular}

Taulukon 1 mukainen vertailu on tutkimuksessa toteutettu molemmista yhtiöistä. Molemmat vertailut osoittavat, että kustannukset eivät merkittävästi poikkea keskimääräisistä urakointihinnoista. Yrityksen johtamistyön muodostamat kustannukset voidaan kattaa lisäämällä työsuoritteisiin tietty kate. Katteella katetaan yhtiölle työskentelevien osakkaiden johtamiskulut ja esimerkiksi mahdollisen kirjanpitoa hoitavan tilitoimiston kulut.

Case-yhtiöiden palvelujen hinnat on määritetty TTS-Kone-ohjelmalla niin, että ne kuvaavat palvelun tuottamisen hintaa, jolla peitetään kustannukset. Jotta yrityksen johtamisen kuluihin ja mahdolliseen tulorahoituspohjaiseen kehittämiseen voidaan saada varallisuutta, täytyy tuloja kasvattaa. Tämä tapahtuu caseyhtiöissä palvelujen hintoihin laskettavalla katteella. Esimerkiksi kuivaamoyhtiön kustannukset kattavalla urakointihinnalla laskettu vuotuinen liikevaihto on $28113 €$. Jos palvelulle lasketaan $10 \%$ :n kate, saadaan kustannukset ylittävää tuottoa $2811 €$. Tämä tarkoittaa kuivauksen hintaan noin $6 € / \mathrm{h}$ korotusta. Ylityksellä voidaan hoitaa yrityksen johtamisen kuluja ja loppu varastoida yhtiöön varallisuutena, tai jakaa ulos osinkoina.

TAULUKKO 2. Osakeyhtiön tuloslaskelman muodostuminen.

\begin{tabular}{ll}
\hline & Myytyjen urakointipalvelujen tuotto \\
- & Muuttuvat kustannukset \\
- & Henkilöstökulut \\
- & Poistot \\
- & Liiketoiminnan muut kulut \\
$=$ & Likevoitto/Tappio \\
- & Rahoituskulut \\
$=$ & Voitto/Tappio ennen tilinpäätössiirtojaja veroja \\
- & Mahdolliset varaukset \\
- & Yhteisövero \\
\hline$=$ & Tilikauden voitto/tappio \\
\hline
\end{tabular}


Molempien case-yhtiöiden tulos muodostuu taulukossa 2 esitetyn kaavan mukaisesti. Taulukko 2 kuvaa yhtiön tuloksen muodostumista kirjanpidollisesta näkökulmasta. Poikkeamasta yhtiön kustannuksiin pohjautuvaan urakointihinnan määrittämiseen on merkittävää huomata, että taulukossa 2 korko ei esiinny poistolaskelman yhteydessä kuten aiemmin, vaan reaalikorkona. Käytännössä tämä tarkoittaa sitä, että tulosta laskettaessa todelliseksi kulueräksi muodostuu vain rahoittajien vaatima lainan korko, yhtiön sijoitusrahastoille maksettava korko ja esimerkiksi leasing-rahoituksen korkokulut.

Yhtiöön sijoitettujen osakepääomien korko on laskennallisesti mukana kustannuksia määritettäessä. Tuloslaskennassa se kuitenkin realisoituu vasta yhtiön verotettavan tuloksen jälkeen mahdollisesti osakepääomalle maksettavina osinkoina. Tämä verotuksen jälkeinen tulos on tilikauden voitto tai tappio. Koska laskennassa kaikelle yhtiöön sijoitetulle pääomalle lasketaan $5 \%$ korko, on tällä kaavalla mahdollista maksaa myös sen verran vuosittain osinkoja sijoitettua osakepääomaa vastaan.

\section{Johtopäätökset}

Haastattelujen perusteella voidaan todeta, että yhteistyön tekeminen yhtiömuotoisesti todellakin on mahdollista. Samalla kuitenkin vahvistui myös käsitys siitä, että yhteistyön mahdollisuudet ovat aina tapauskohtaisia. Kaikki yhtiöt olivat syntyneet jostakin tarpeesta ja yhtiön päämäärä ohjasi niiden toimintaa. Päämäärät vaihtelivat palvelun tuottamisesta elannon ansaitsemiseen.

Myös tietynasteinen kustannustehokkuus palvelujen tuottamiseen on selvästi mahdollista saavuttaa. Tästä viestii palvelun haastateltujen tyytyväisyys palvelun hinnoitteluun. Kuivaamoyhtiöiltä saatujen konkreettisten lukujen valossa haastatellut yritykset pystyivät myymään palvelunsa 0-katteella noin 30-50 \% työtehoseuran vuoden 2012 tilastoimaa rahtikuivauksen keskihintaa edullisemmin. Hintaa toki keinotekoisesti laskee se, että yhteistyöyritysten käyttämä hinta ei sisällä työtä, jonka kuivaamoa käyttävä osakas tekee kuivauksen aikana. Rahtikuivauksessa kuivauspalvelun tarjoaja huolehtii kuivaamon käytöstä.

Yhtiön toiminnan onnistumisen kokeminen vaikutti olevan suhteessa siihen, kuinka yhtiön työn organisoinnissa oli onnistuttu. Kuivaamoyhtiöiden osalta yhtiön toiminnan suhteuttaminen tilojen toimintaan vaikutti helpoimmalta, sillä kuivaamo ei vaatinut osakkailtaan työpanosta. Mitä enemmän yhtiö sitoi osakkaita, sitä tarkemmin osakkaiden on hahmotettava omat vapautettavissa olevat resurssinsa. Jos yhtiön toiminta lepää osakkaiden varassa, eivätkä he pysty täysipäiväisesti työskentelemään sesongilla, yhtiön koneiden käyttöaste kärsii, mikä vaikuttaa hinnan kilpailukykyisyyteen.

Haastatelluissa kävi ilmi, että osakeyhtiö yhtiömuotona yhteistyössä toimii parhaiten silloin, kun yhtiöihin tarvitaan kohtalaisen paljon pääomaa, ja osakkaiden työskentely yrityksessä on vähäistä. Osake-yhtiö on hyvä tapa kerätä pääomaa yhtiön käynnistämiseen ja hajauttaa riskiä. Vähäinen työskentely taas tuo osakkaiden työn korvaamisen helposti toteutettavaksi ja edulliseksi ilman että verottaja katsoo osakkaiden olevan työsuhteessa yhtiöön.

Osakeyhtiö tuottaa osakkailleen voittoa - osuuskunta tuottaa osakkailleen palveluja. Tämä kantava ajatus on yksi hyvä ohjenuora yhtiömuodon valintaan. Osakeyhtiön suhde palvelua ostaviin tiloihin tulisi muistuttaa urakointisuhdetta. Palvelun hinnan tulee jo verolainsäädännönkin vuoksi olla sama, myydään palvelua sitten osakkaille tai ulkopuolisille. Toimivan yhtiön perustamisen kantava ajatus voisikin olla "Luodaan alueelle urakointipalvelu, jota siellä ei vielä ole".

Case-sovelluksilla on esitetty kaksi tilannetta, joissa koneyhteistyöyhtiön perustaminen on mahdollista. $\mathrm{Ne}$ molemmat ovat yksittäisiä tapauksia, mutta antavat lähtökohdat pohtia yhteistyön toteuttamisen mahdollisuuksia omassa toimintaympäristössä. Niiden tarkoituksena on tuoda esille sopimusteknisiä asioita ja antaa eväitä oman tilanteen taloudellisuuden kartoittamiseen.

Laskelmat on toteutettu paljolti TTS-Kone ohjelman aloitusarvoilla, ja ne lähinnä kuvaavat sitä, onko työkoneen käyttöaste riittävän suuri kattamaan kustannukset. Jokainen konehankinta on erilainen ja tarkempien pääomakustannusten saamiseksi jokainen tapaus pitää laskea erikseen. Myös koneiden todellinen työteho vaihtelee ohjearvoista. Käytännönkokemuksia laskennan pohjaksi kannattaa hakea koneen jo hankkineilta yrittäjiltä.

Koska koneiden pääomakustannusten laskenta perustuu malliyhtiöiden kohdalla poistoihin, eivät ne täydellisesti kuvaa yhtiön alkuvuosien kustannuksia. Poistolaskelma jakaa pääoman kulut koneen käyttövuosille. Todellisuudessa etenkin pankkilainan osuus pääomakustannuksista todennäköisesti on korkeampi, koska laina aikataulu on koneen käyttöikää lyhempi. Tätä laskennallista eroa voidaan kompensoida 
olemalla maksamatta osakkeille osinkoa ensimmäisinä vuosina ja ohjaamalla sitä varallisuutta vieraan pääoman maksuun. Edellä mainituista syistä johtuen maksuvalmiuslaskelman tekeminen yhtiön ensimmäisille vuosille on todella tärkeää ja luultavasti parantaa myös rahoittajan suhtautumista yhtiöön. Jonkinlainen maksuvalmiuslaskelma on todennäköisesti myös rahoittajan rahoitusvaatimuksissa.

Laskelmat osoittavat, että tila omisteisen yhtiön kautta tehty konetyö ei lähtökohtaisesti ole sen kalliimpaa tai sen halvempaa, kuin urakoinnilla toteutettu palvelu. Syy, miksi sovellukset vertaavat palvelun hinnoittelua juuri urakointiin on, että siitä on tilastoitua tietoa. Tilojen itse toteuttaman konetyön kannattavuudesta en ole löytänyt tilastoitua aineistoa.

Mielestäni järkevin tapa lähteä miettimään yhteistyötä mukailee edellä olevia case-sovelluksia. Ensin kartoitetaan markkina-alue. Sen jälkeen kartoitetaan halukkaat osakkaat ja heidän luovutettavissaan oleva työpanos. Markkinoiden ja resurssien selvittyä mietitään sopiva konekanta yhtiölle ja laaditaan laskelmat urakointihinnoista ja yhtiön taloudesta. Jos laskelmat osoittavat toiminnan järkeväksi hankitaan rahoitus ja perustetaan yhtiö.

Esitettyyn kysymykseen, onko yhteistyön tekeminen yhtiömuotoisesti mahdollista, voidaan vastata yksiselitteisesti: kyllä on. Yhtiö on vain instrumentti, jolla yhteistyötä voidaan tehdä, ja selkeyttää yhteistyön rahaliikennettä ja kustannuksia. Samaan lopputulokseen voidaan päästä myös perinteisessä yhteiskoneisiin perustuvassa yhteistyössä, mutta tällöin toiminnan pohjalle on luotava säännöstö itse. Osakeyhtiölainsäädäntö antaa velvoitteet kirjanpitoon ja rahaliikenteeseen, sekä myös perustamiseen ja purkamiseen. Erillisen juridisen toimijan hallinnassa olevat koneet voivat myös auttaa ymmärtämään yhteiskoneen käytön ja huollon vaatimukset eri tavalla.

Sopiiko yhtiömuotoinen koneyhteistyö kaikille? Vastaus on yksiselitteisesti: Ei. Mutta samalla ei sovi myöskään muunlainen yhteistyö. Yhteistyö vaatii tiloilta oman toiminnan ymmärtämistä ja strategista ajattelua myös tilatasolla. Kun ymmärretään ja suunnitellaan oman tilan toiminta, voidaan se myös istuttaa yhteen yhteistyön kanssa. Yhteistyön laajuus ja muoto vaikuttavat todella paljon siihen, kenelle yhteistyötä voi suositella. Esimerkiksi kuivaamon omistajana toimiminen ei välttämättä sido kuin pääomaa ja yhtiökokoukseen osallistumisen. Muutoin toiminta voi muistuttaa rahtikuivaukseen viljan toimittamista.

Ongelmallisin muoto yhteistyöstä ovat varmasti työvaiheet, jotka sitovat paljon osakkaiden työpanosta, ja samanaikaisesti työ tehdään pääosin osakkaiden tilalla. Tällöin työn korvaaminen on kaikkein haastavinta. Palkanmaksuna toteutettu korvaus on yksinkertaisin, mutta palkan sivukulujen vuoksi se muodostaa yhtiön kautta tehdyn työn epäedulliseksi pelkkään yhteisomistajuuteen verrattuna.

Yhteistyöyhtiön täytyykin tehokkaammalla koneiden käyttöasteella ja tehokkaammilla työvaiheilla pystyä tuottamaan kustannuksiin etuja, joilla sivukulujen kustannukset nujerretaan. Todellisuudessa sivukulujen määrä tuskin kohoaisi ongelmaksi, sillä työvoiman osuus myydystä palvelusta voidaan eriyttää, ja omalle tilalle työskenneltäessä yhtiöltä voidaan ostaa pelkkää konevuokrauspalvelua. Tällöin työvoimana toimiva yrittäjä ei tarvitse kustantaa yhtiön kautta omaa palkkaansa. Työskenneltäessä yhtiön kautta toisen tilalla tilanne puolestaan yksinkertaistuu, koska palkan maksut hoituvat kaikki samasta yhtiöstä.

Yhteistyöyhtiöiden toiminnalliset edellytykset urakointiin verrattuna tutkittiin työn case-osiossa. Sen pohjalta voidaan todeta, että palvelun hinta on tapauskohtaista, ja tuskin muodostuu esteeksi yhteistyöyhtiö ajatukselle. Toisaalta palvelun tuottaminen itse ei ole myöskään selvästi urakointia halvempaa. Näin ollen motivaatio yhtiön perustamiseen on lähtökohtaisesti muualla. Esimerkkejä lähtökohdista voi olla tarve, palvelun varmuuden turvaaminen ja halu vaikuttaa voimakkaammin ulkoistetun palvelun tuottamiseen. 


\section{Lähteet}

Agrimarket. 2014. Rehuviljan laatu hallintaan. [verkkodokumentti] [viitattu: 20.10.2014] Saatavissa: http://www.agrimarket.fi/Maatalous_ja_Elaimet/karjatilan-kasvuohjelma/Nautakarjatila/rehuvilja/ Eläketurvakeskus. 2014. Eläkejärjestelmät. Suomi. Eläketurvan kattavuus ja vakuuttaminen. [vii-tattu: 22.12.2014] Saatavissa: http://www.etk.fi/fi/service/yel-yritt\%C3\%A4j\%C3\%A4t/237/yel-yritt\%C3\%A4j\%C3\%A4t Finnvera. 2015. Tuotteet ja UKK. Lainat. Finnvera-laina. [viitattu: 11.1.2015] Saatavissa: http://www.finnvera.fi/Tuotteet-ja-UKK/Lainat/Finnvera-laina Hopeasaari, V. 2014. Palkka voi olla osinkoa edullisempaa. Taloushallinto. [verkkodokumentti] [viitattu: 23.12.2014] Saatavissa: http://taloushallintoliitto-fibin.directo.fi/@Bin/df79466d02b35409f8986433406be077/1419350266/application/pdf/10136/Palkka\%20voi\%20ola\% 20osinkoa\%20edullisempaa.pdf

Immonen, R., Ossa, J. \& Villa, S. 2014 Osakeyhtiön pääoman hallinta. Viro: Print Best

Kovalainen, M. 2007. Eri yritysmuotojen verotus. Teoksessa: Enroth, A., Österman, PP. \& Harmoinen, T. (toim.) 2007 Maatilayrityksen yhtiöittäminen. Keuruu: Otavan Kirjapaino Oy

Laki veromenettelystä. 18.12.1995/1558. Finlex. Lainsäädäntö. [Viitattu 12.1.2015]. Saatavissa:https://www.finlex.fi/fi/laki/ajantasa/1995/19951558?search\%5Btype\%5D=pika\&search\%5Bpika\%5D=laki\%20vero tus\#L1

Maatalousyrittäjien eläkelaki. 22.12.2006/1280. Finlex. Lainsäädäntö. [Viitattu 23.12.2014]. Saatavissa: https://www.finlex.fi/fi/laki/ajantasa/2006/20061280?search\%5Btype\%5D=pika\&search\%5Bpika\%5D=maatalous\#L3P 15

MELA. 2014. Eläkevakuutus. MYEL-vakuutus. [viitattu:23.12.2014] Saatavissa: http://www.mela.fi/fi/elakevakuutus/myel-vakuutus/kenelle-vakuutus/yhtiomuotoinen-toiminta Osakeyhtiölaki. L 21.7.2006/624. Finlex. Lainsäädäntö. [Viitattu 19.10.2014]. Saatavissa: http://www.finlex.fi/fi/laki/ajantasa/2006/20060624

Osuuspankki. 2015. a. Henkilöasiakkaan. Lainat. Vakuudet. [viitattu: 11.1.2015] Saatavissa: https://www.op.fi/op/henkiloasiakkaat/lainat/vakuudet?id=20700\&srcpl=8

Osuuspankki. 2015. b. Yritysasiakkaat. Rahoitus. Investoinnit. Leasing. [viitattu: 11.1.2015] Saatavissa: https://www.op.fi/op/yritysasiakkaat/rahoitus/investoinnit/leasing?id=60202\&srcpl=8

Palva, R. 2013. Konetyön kustannukset ja tilastolliset urakointihinnat. TTS:n tiedote. Maatalous-työ ja tuottavuus. 3/2013 (645). [verkkojulkaisu] [viitattu 15.2.2015] Saatavissa: http://webd.savonia-amk.fi.ezproxy.savoniaamk.fi/Opintomateriaali/TTS/mati/2013/2013_3_mati645_

Konetyon\%20kustannukset\%20ja\%20tilastolliset\%20urakointihinnat.pdf

PRH. 2015. Patentti- ja rekisterihallitus. Kaupparekisteri. Osakeyhtiö. Perustaminen. [viitattu 20.1.2015] Saatavissa: http://www.prh.fi/fi/kaupparekisteri/osakeyhtio/perustaminen/

Sivukulujen laskennan peruste TTS-Kone Ohjelmassa 2015-02-23. [Sähköpostikeskustelu Janne Karttusen kanssa.] Tuloverolaki. L 30.12.1992/1535. Finlex. Lainsäädäntö. [Viitattu 1.3.2015]. Saatavissa: https://www.finlex.fi/fi/laki/ajantasa/1992/19921535?search\%5Btype\%5D=pika\&search\%5Bpika\%5D=tuloverolaki Valtiovarainministeriö. 2014. Verotus. Henkilöverotus. [viitattu 22.12.2014] Saatavissa: https://www.vm.fi/vm/fi/10_verotus/03_elinkeinoverotus/01_yhteisovero/index.jsp Verohallinto. 2015a. Syventävät vero-ohjeet. Elinkeinoverotus. Osakkeet, osingot ja peitelty osingonjako. Peitelty osinko. [viitattu 12.1.2015] Saatavissa: http://www.vero.fi/fi-

FI/Syventavat_veroohjeet/Elinkeinoverotus/Osakkeet_osingot_ja_peitelty_osingonjako/Peitelty_osinko(10209) Verohallinto. 2015b. Syventävät vero-ohjeet. Elinkeinoverotus. Yritysmuodon muutos ja yritysjärjestelyt. Toiminnan muutos osakeyhtiöksi. [viitattu 23.1.2015] Saatavissa: http://www.vero.fi/fi-

FI/Syventavat_veroohjeet/Elinkeinoverotus/Yritysmuodon_muutos_ja_yritysjarjestelyt/Toimintamuodon_muutos_osak eyhtioksi(26050)

Verohallinto. 2015c. Yritys- ja yhteisöasiakkaat. Osakeyhtiö ja osuuskunta. Tuloverotus. [viitattu 23.2.2015]

Saatavissa: http://www.vero.fi/fi-FI/Yritys_ja_yhteisoasiakkaat/Osakeyhtio_ja_osuuskunta/Tuloverotus

Veronmaksajat. 2015. Vuodenvaihteen veromuutoksia 2015. Pääomatulojen verotus [viitattu: 10.2.2015] Saatavissa: http://www.veronmaksajat.fi/palkka-ja-elake/verotus-2015/

Yrittäjät. 2014. Osakeyhtiön perustamistoimet ja yhtiömuodon sääntely. [viitattu 28.12.2014] Saa-tavissa: http://www.yrittajat.fi/fi-FI/minustakoyrittaja/perustamistoimet/osakeyhtio/

Österman, P. 2007. Yhtiömuodon valinta Teoksessa: Enroth, A., Österman, P. \& Harmoinen, T. (toim.) 2007 Maatilayrityksen yhtiöittäminen. Keuruu: Otavan Kirjapaino Oy 